\title{
Environmental and community impacts of waste disposal in OR Tambo District Municipality (South Africa)
}

\author{
S. Buso ${ }^{1}$, M. D. V. Nakin ${ }^{2}$, A. Abraham ${ }^{1}$ \& C. M. Musampa ${ }^{1}$ \\ ${ }^{I}$ Department of Environmental Science, Walter Sisulu University, \\ South Africa \\ ${ }^{2}$ Risk and Vulnerability Assessment Centre, Walter Sisulu University, \\ South Africa
}

\begin{abstract}
Increasing urbanization trends have seen natural ecosystems increasingly being replaced by urban development. Rapid rate of urban growth is causing social and environmental strains. The magnitude of the problem is partially reflected by the higher amount of solid waste generated. Consequently, common features of urban areas are stinking heaps of uncollected waste, waste disposed haphazardly by roadsides, open spaces, valleys, drains and rivers, non-compliance by waste disposal facilities. Spatial planning and environmental protection through rapidly growing population had influenced changes in ways at which waste was managed. The aim of this study was to identify the impact of waste management to the environment and communities in OR Tambo District Municipality. To achieve this, field observations and visits to local municipalities were conducted, water quality parameters $(\mathrm{pH}$, Temperature, and Dissolved Oxygen) were measured on site using the Eutech Cyberscan series 600 portable water quality meter and water samples were taken to test for the concentration of nitrates and phosphates. A two-way analysis of variance (ANOVA) was used for statistical analyses. Questionnaire surveys and interviews were conducted in schools and clinics adjacent to landfill sites to investigate community impacts and analysed using SPSS statistics 21. There were significant differences in dissolved oxygen and $\mathrm{pH}$ among sites in municipalities. There were challenges identified in communities with negative implications ranging from socially, environmentally and on health. These results highlight the need for waste minimisation,
\end{abstract}


community-based waste management, environmental education, law enforcement and safe disposal in local municipalities.

Keywords: environment, minimisation, water quality, management, impacts, disposal, illegal dumping, awareness, municipalities, local municipalities.

\section{Introduction}

Cities, which have supported and cultivated the present human civilization, are an inseparable part of the natural environment on earth (Xudong [1]). Urban activities and development rely upon the surrounding natural environment for resources and energy inputs. In the same time, cities also takes advantage of the natural environment for storing and decomposing wastes emitted from it. Due to increasingly intensified urban activities, population growths and limited carrying capacity of the natural environment, urban development recently has caused serious, complex environmental problems, such as air and water pollution, shortage of waste disposal space, resource depletion, ecosystem lose and global warming (Gondo [2]). These problems in turn hindered further development of cities. For example, they threatened public health, raised the costs of urban activities, and increased the frequencies of natural disasters.

The researchers observed significant elevation of water indices such as $\mathrm{pH}$, biochemical oxygen demand (BOD), nitrate and phosphate. It is well known that oxygen depletion in water bodies could cause fish death while increase in BOD signifies high load of organic matter. Also, organic matter decomposition in surface water produce inorganic nutrients such as ammonia, nitrate and phosphorus with resultant effects of eutrophication and other serious ecological problems of such water body (Ogunfowokan et al. [3]). These are all due to the haphazardly disposed waste and end up affecting surface water (Taiwo et al., [4]).

Typically, material flows in an urban system pass through several major processes from industrial production to final disposal of wastes (Hayashi [5]). Increasing urbanization trends have seen natural ecosystems increasingly being replaced by urban development. One of the most affected components of urban landscapes is open space amongst others. Open spaces are a victim to illegal dumping of waste and other substances like rubble and construction waste (Mahdavinejada and Abedia [6]). Gondo [2] sees illegal land use activities competing for space. Contesting uses are waste disposal, illegal land use developments such as informal settlements, informal business, urban agriculture and livestock grazing.

Constitution of the Republic of South Africa (Act 108 of 1996) states that, all people have a right to an environment that is not detrimental to human health and imposes a duty to the state to promulgate legislation and to implement policies to ensure that this right is upheld. National Environmental Management Act (No 107 of 1998) (NEMA) provides for co-operative governance by establishing principles and procedures for decision-makers on matters affecting the environment. An important function of NEMA is to serve as an enabling Act for the promulgation of legislation to effectively address integrated environmental 
management to the responsible parties. NEMA entails two principles amongst others, the principle of sustainable development and environmental protection.

Kalule [7] is of the view that in the past few decades waste management planning has moved on from being purely based on a remove and dump system, to more sophisticated Integrated waste management planning systems based on waste hierarchies. This was also revealed in the study by Williams [8] that at the beginning waste was required to be collected and transported by scavengers to an open dump one mile outside the city. This was regardless of the environment and its surroundings. Spatial planning and the environment through the rapidly growing population had influenced changes in all ways at which waste was managed. Therefore this means that waste management is also influenced by spatial planning and the environmental management.

\section{Materials and methods}

The field visits were conducted in local municipalities (which were Ingquza Hill, Nyandeni, King Sabatha Dalindyebo $\{\mathrm{KSD}\}$ and Mhlontlo). Results were discussed in all scenarios from one site to another and were presented in order to reflect situation and the conditions of the district. Field observations on environmental and social/community impacts of waste disposal and visit to local municipalities in OR Tambo District Municipality were conducted. Water quality parameters ( $\mathrm{pH}$, Temperature, and Dissolved Oxygen) were measured in site using the Eutech Cyberscan series 600 portable water quality meter and water samples were taken using sampling bottles to test nitrates and phosphates before and after waste disposal areas. A two way analysis of variance (ANOVA) was used for statistical analysis. Questionnaire surveys were conducted for community impacts around the landfill sites using a random sampling and analyzed using SPSS statistics 21 and interviews were conducted in schools and clinics that were in the vicinity of the landfill sites.

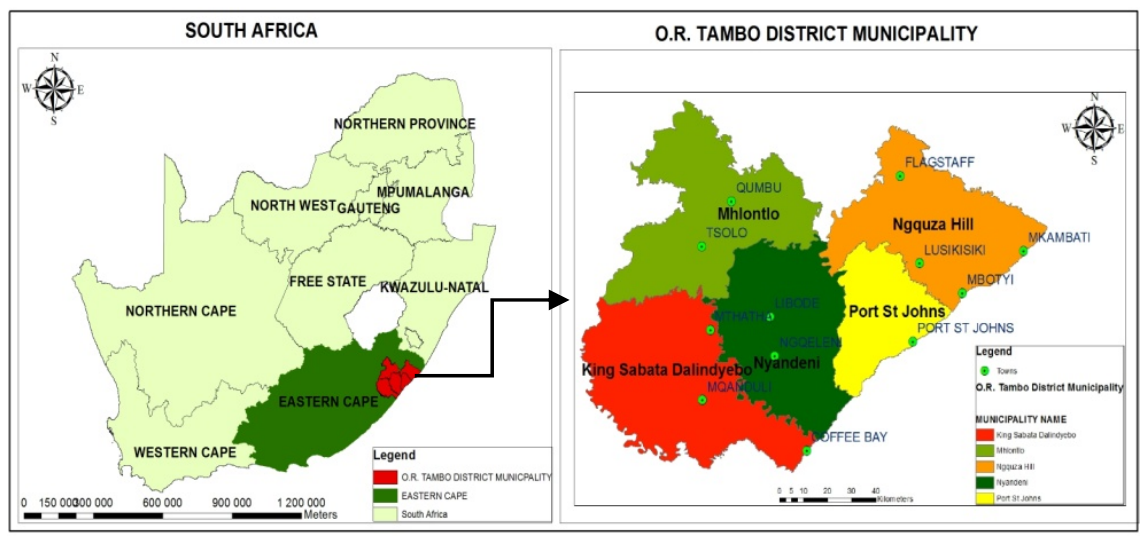

Figure 1: Map showing the study area. 


\section{Results}

\subsection{Water quality}

ANOVA results showed significant difference $(\mathrm{p}<0.05)$ on dissolved oxygen among sites within municipalities (Table 1). Post-hoc test revealed that some of the site were significantly different with KSD (site 2), Nyandeni (site 1 and 4) as well as Mhlontlo (site 2) being significantly different to one another (Figure 2).

Table 1: Results of the two-way ANOVA based on the mean dissolved oxygen in municipality found in OR Tambo District municipality (* indicates significant difference at $\mathrm{p}<0.05)$.

\begin{tabular}{|c|c|c|c|c|c|}
\hline Effect & SS & df & MS & F & p \\
\hline Municipality & 42.2134 & 3 & 14.0711 & 7.9414 & $0.01^{*}$ \\
\hline Site & 0.3848 & 2 & 0.1924 & 0.1924 & 0.89 \\
\hline Error & 31.8936 & 18 & 1.7719 & & \\
\hline
\end{tabular}

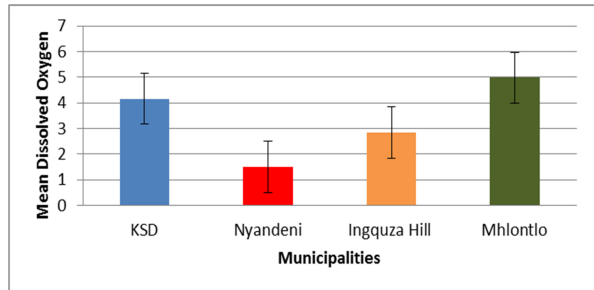

Figure 2: Mean ( \pm SE) number of dissolve oxygen (DO) found in municipalities in OR Tambo District Municipality.

The results of the two-way ANOVA showed that there was a significant difference $(\mathrm{p}<0.05)$ on temperature in all municipalities (Table 2) except KSD (site 4) and Mhlontlo (site 1) (Figure 3).

Table 2: Results of the two-way ANOVA based on the mean temperature in municipalities found in OR Tambo District municipality (* indicates significant difference at $\mathrm{p}<0.05)$.

\begin{tabular}{|c|c|c|c|c|c|}
\hline Effect & SS & df & MS & F & p \\
\hline Municipality & 79.426 & 3 & 26.475 & 38.018 & $0.01 *$ \\
\hline Site & 9.952 & 2 & 4.976 & 7.146 & 0.05 \\
\hline Error & 12.535 & 18 & 0.696 & & \\
\hline
\end{tabular}

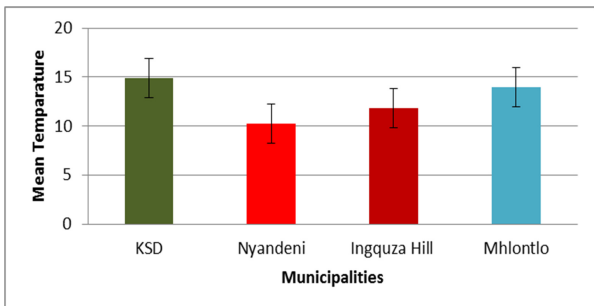

Figure 3: Mean ( \pm SE) temperature found in municipalities in OR Tambo District Municipality. 
ANOVA results showed significant difference $(\mathrm{p}<0.05)$ in nitrates in one municipality KSD (site 4) (Table 3) and Mhlontlo (site 1) that significant different has occurred (post hoc) (Figure 4).

Table 3: Results of the two-way ANOVA based on the nitrates in municipalities found in OR Tambo District municipality (* indicates significant difference at $\mathrm{p}<0.05)$.

\begin{tabular}{|c|c|c|c|c|c|}
\hline Effect & SS & df & MS & F & p \\
\hline Municipality & 99.3 & 3 & 33.1 & 3.96 & $0.02^{*}$ \\
\hline Site & 241.3 & 2 & 120.7 & 14.42 & $0.01^{*}$ \\
\hline Error & 150.7 & 18 & 8.4 & & \\
\hline
\end{tabular}

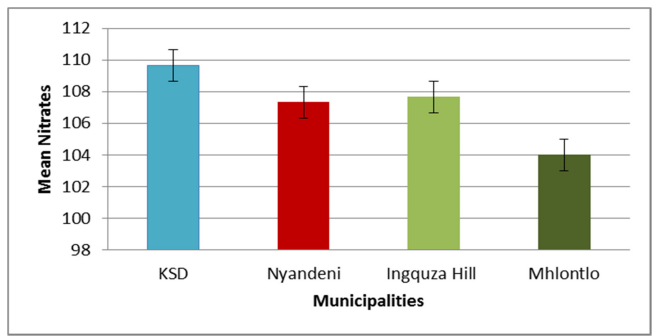

Figure 4: Mean ( \pm SE) number of nitrates found in municipalities in OR Tambo District Municipalities.

There was a significant difference $(\mathrm{p}<0.05)$ in $\mathrm{pH}$ shown by ANOVA results (Figure 5), sites that were significantly different were KSD (site 3), Ingquza Hill (site 1 and 4) and Mhlontlo (site 3) (Table 4).

Table 4: Results of the two-way ANOVA based on the mean $\mathrm{pH}$ in sites found in OR Tambo District municipality $(*$ indicates significant difference at $\mathrm{p}<0.05)$.

\begin{tabular}{|c|c|c|c|c|c|}
\hline Effect & SS & df & MS & F & p \\
\hline Municipality & 0.564 & 3 & 0.188 & 8.28 & $0.01^{*}$ \\
\hline Site & 0.774 & 2 & 0.387 & 17.07 & 0.07 \\
\hline Error & 0.408 & 18 & 0.023 & & \\
\hline
\end{tabular}

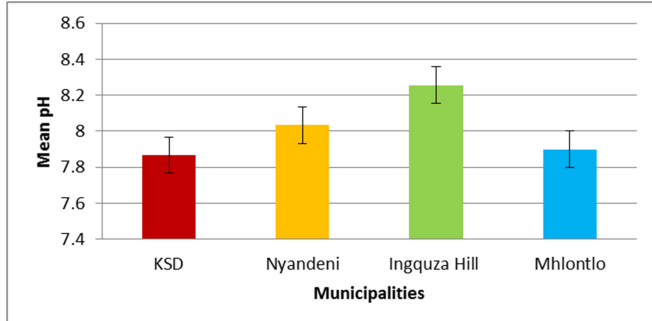

Figure 5: Mean ( \pm SE) number of $\mathrm{pH}$ found in site in OR Tambo local municipalities. 


\subsection{Community impacts}

Social impact that was most experienced by municipalities was the attraction of people and animals which was popular in all municipalities, followed by diseases spreading from landfill sites to animals and that was found mostly in Nyandeni followed by Ingquza Hill and KSD. Landfill sites also attracted thieves that come to houses, and the most impacted municipality was KSD followed by Ingquza Hill (Figure 6).

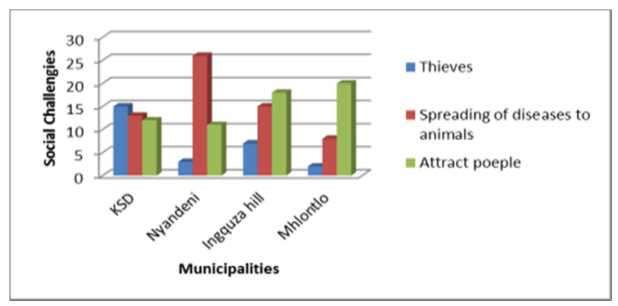

Figure 6: Social impacts of landfills on communities.

The dirty environment was the most impact in most municipalities which was followed by smoke mostly in Ingquza Hill. Impacts like bad smell which was mostly highlighted in Mhlontlo and flies which was glaring in KSD and mosquitoes were also found as environmental impacts (Figure 7).

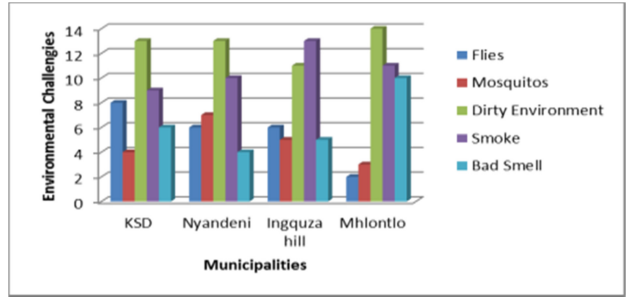

Figure 7: Environmental impacts of landfills.

The most experienced health issue from the landfill sites in municipalities was the skin problems followed by asthma in KSD and Ingquza and stomach problems and TB were following in municipalities like KSD, Nyandeni and Ingquza Hill. Sinus was also identified in all municipalities (Figure 8).

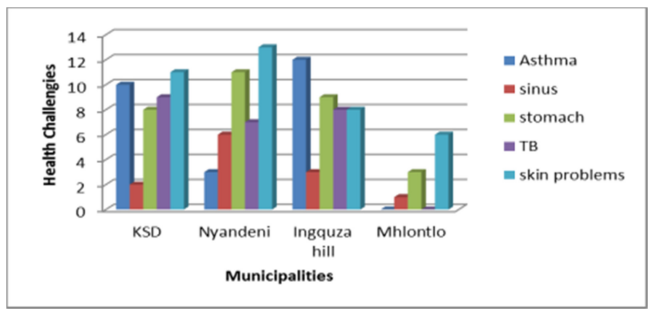

Figure 8: Health impacts of landfills. 


\section{Discussion}

Impacts to social, environmental and health factors of waste disposal were identified as key findings to the study. Significant difference was also indicated in selected sites in OR Tambo in terms of dissolved oxygen, temperature, nitrates and $\mathrm{pH}$. These differences occur both as a result of natural variability, anthropogenic activities and pollutant inputs (Taiwo et al. [9]). Factors like establishment of communities and landfill sites, distance between residences and landfill sites, were also identified as contributing factors that added significance to these key findings. As part of the logistics management and spatial planning for waste management, it was important to develop the adoptability of the system for better management around these parameters (Rahardyan et al. [10]).

Results of the study indicate significant difference among site with p-value less than 0.05 on dissolved oxygen. Post-hoc tests have revealed that some of the sites are significantly different with KSD (site 2), Nyandeni (site 1 and 4 ) as well as Mhlontlo (site 2). It is well known that oxygen depletion in water bodies could cause fish death while increase in BOD signifies high load of organic matter (Taiwo el al. [9]). Presence of waste material as well as sewage discharge was identified in rivers in OR Tambo and this was associated with varying levels of Dissolved Oxygen which was relatively low. This is what was also confirmed by Izonfuo and Bariweni [11], that the impact of human activities around the Creek was felt on the water body as low DO values were recorded during the wet season due to urban run-off.

The results of the two-way ANOVA showed that there was a significant difference on temperature in all site except KSD (site 4) and Mhlontlo (site 1) as the p-value was less than 0.05 . The researchers reported a significant seasonal and the day time effect on temperature in the surface water (Taiwo [12]). Based on such, this was assumed to be the reason of the differences identified in the temperature in OR Tambo since they were taken in different times of the day. However, temperature is an essential parameter to influence the photosynthesis in water, physiological responses of aquatic organisms and decomposition of organic matter and subsequent bio-chemical reactions (Pankaj Kumar et al. [13]). It is also one of the most important factors controlling growth and biological radiations taking place in water for organisms inhabiting aquatic media (Nagendra and Tiwari [14]).

ANOVA results showed a significant difference $(p<0.05)$ in nitrates only in KSD (site 4) and Mhlontlo (site 1) that significant different has occurred (posthoc). Organic matter decomposition in surface water produced inorganic nutrients such as ammonia, nitrate and phosphorus with resultant effects of eutrophication and other serious ecological problems of such water body (Ogunfowokan et al. [15]). Agriculture remains the major source of nitrate and phosphate pollution of surface water due run off (Taiwo [12]). This is envisaged to be the reasons of the high levels of nitrates in the selected sites because of the availability of waste material in surface water and agriculture activities around the sites. The higher inflow of water and consequent land drainage cause high value of nitrate in river water (Hemant et al. [16]). 
There was a significant difference $(\mathrm{p}<0.05)$ in $\mathrm{pH}$ shown by ANOVA results, sites with significantly different were KSD (site 3), Ingquza Hill (site 1 and 4) Mhlontlo (site 3). Activities of micro-organisms, temperature and pollutant inputs are responsible for the chemical characteristics of surface water (Ibiyemi [17]). The presence of organic matter content may influence low $\mathrm{pH}$ value. Organic matter lock-up substantial amounts of calcium, sodium and magnesium in exchange for free hydrogenous substance which is acidic (Hemant et al. [16]).

The $\mathrm{pH}$ levels in selected sites ranges between 7.8 to 8.3 which remain relatively within the allowable WHO range of 7.0 to 8.5 based on the WHO guidelines (Hemant et al. [16]). The usual and most neglected cause of water pollution is uncontrolled dumping of municipal solid waste (Nagendra and Tiwari [14]). But monitoring the water quality is very important for environmental safety, constant natural water analysis for physical and chemical properties including traces of element content are very important for public health (Taiwo et al. [9]).

Social impact that were identified in this study were that landfill site have tended to be home of house backers because in municipalities like KSD Mthatha town there were informal houses that were built inside the landfill site, so people that stay there were identified as thieves by the communities, and that has contributed $30.8 \%$ of the respondents. It was also indicated that animals and people more especial school kids are being attracted by these landfill and the school kids were even dodging school just to collect things in the landfills. This was also witnessed by Kimani [18] that some landfill sites being open space, encourages and attracts many children to turn to street life since they scavenge for items from the dump site which they sell. He also alluded that schools such as St John Informal School in Korogocho have reported cases of pupils escaping from school to work at the dump site (WHO [19]). There were reported incidents of animal death in municipalities like Nyandeni and Ingquza that goats and cattle eat dangerous things that lead them to death and that have caused conflict between the municipality and the communities.

These were also revealed in the study by Owusu [20] that the challenges of rapid urbanization with respect to waste management, and the burdens are placed on poor urban residents in Sabon Zongo, a poor community in Accra. He further argues that the health and environmental consequences of poor waste management are acknowledged as they have both direct and indirect links to the social consequences. From the public perception as worst impacts of present solid waste disposal practices are seen direct social impacts such as neighbourhood of landfills to communities, breeding of pests and loss in property values (Bandara and Hettiarachchi [21]).

Environmentally impacts that were identified in this study were dirty environment (littering, windblown papers and plastics), smoke, fleas, mosquitoes and odour. It was indicated that people who were residing in the landfills more especially in Mthatha town were burning tires and other objects for warmth at night and that cause smoke to go around the residences that were around the landfill site. Papers and plastics were always blown by wind to the residences 
and cause dirty to the environment as most of landfills were open dump. According to the interview that was held at Ikhwezi Lokusa disabled school that was less than 200 meters from Mthatha landfill site, flies always move from the landfill to the school and that cause problems as the school was having children with disabilities and the smoke was also affecting the school mostly in that regard. Bandara and Hettiarachchi [21] is of the view that inappropriate solid waste disposal is a major threat to the environments of developing countries since most of the solid waste generated end up directly in open dumps which are uncontrolled and overloaded. Air pollution from landfill emissions, ground water pollution from leachate, health problems due to breeding of disease causing pests and social problems such as decreasing land values and aesthetic appeal of an area are some associated problems.

The study had also found out that there were also health impacts that were affecting communities surrounding landfill sites, such identified impacts were smoke related diseases, skin problems and diarrhoea as also witnessed by Bandara and Hettiarachchi [21]. This was also witnessed when interviews were conducted in some of the clinics that people around some landfill sites were getting their health services from. In the study by Kimani [18] it was revealed that the high levels of lead in the soil samples analyzed are negatively impacting on the communities living near the dumpsite which is evidenced as well by the fact that half of the children examined had blood lead levels equal to or exceeding the internationally accepted toxic levels $(10 \mu \mathrm{g} / \mathrm{dl}$ of blood). This in turn led to clinical symptoms such as headaches, chest pains and muscular weakness being manifested in the children (WHO [19]).

According to the minimum requirements for waste disposal by landfill, site selection is the fundamental step in the development of a landfill. This step has far reaching economic, environmental and public acceptance implications. The landfill site selection process is only complete once the Department has found a site feasible on the basis of a feasibility study. Solid waste management facilities to be accepted they should be environmental friendly, economically sound, and socially acceptable, because if they are not accepted may be opposed (Rahardyan et al. [10]). This may be the results in OR Tambo District Municipality, because the states of landfill sites were not welcoming to the eyes of the public, except for Port St John's. Rathi [22] is of the view that municipal corporations of the developing countries are not able to handle increasing quantities of waste, which results in uncollected waste on roads and in other public places. There is a need to work towards a sustainable waste management system, which requires environmental, institutional, financial, economic and social sustainability (UNCHS [23]).

The objectives of landfill site selection are to ensure that the site to be developed is environmentally acceptable and that it provides for simple, costeffective design which in turn provides for good operation. In OR Tambo District Municipality there were nine landfill site that were in operation, five were found to be not having licenses and four were operating legally even though they were not operating according to license conditions except that one of Port St John's. The establishment and maintenance of buffer zones, or set back 
distances, is enforceable in terms of the Health Act, 1977 (Act 63 of 1977), which makes provision for measures necessary to prevent any nuisance, unhygienic or offensive condition that is harmful to health. The width of the buffer zone is prescribed for Communal and Small landfills. For other landfills, however, the width of the buffer zone is dependent on the classification of the landfill and any Site Specific Factors that may affect its environmental impact upon investigation by Independent Assessment Practitioners.

Social and economic trends have changed in O.R Tambo District since 1994 where people were moving from rural areas to town in search for better services and jobs more especial after the establishment of the social support housing programs. The high rate of urbanization in African countries implies a rapid accumulation of refuse, social, economic changes and rapid land use that most countries have witnessed since the 1960s have also contributed to increases in waste generated per capita (Onibokun [24]).

The shortage of disposal capacity, especially land filling capacity, continued to be a major driver for volume reduction and waste diversion from landfill (Bai and Sutanto [25]). In the city of Mthatha (Mthatha town) space for land filling has been a challenge for a couple of years, this was found when conducting an interview with KSD local municipality and Ikhwezi Lokusa disabled school. The land fill site in Mthatha was in the middle of the residential area and next to the school. According KSD local municipality, plans were to remove and rehabilitate the land fill site long time ago as there was also a new development of the social support houses just less than 100 meters from the land fill site, but the problem was that the municipality had run short of space and the available land is a communal land which is highly affected by political challenges.

Also in Lusikisiki and Flagstaff in Ingquza local municipality, siting a space for land filling was faced with both political and environmental pressures because the available land is communal, and the available land for the municipality cannot get environmental authorisation, as the current landfill site boarded by residential areas. In spite of the progress in technologies and strengthening of environmental standards, political pressure remained unsolved. For example, due to insufficient public participation in the planning stage, siting new landfills in Ontario, in Canada appeared to be difficult, and exporting waste to Michigan, in the US for land filling caused political attention of the two countries (Hostovsky [26]).

\section{Conclusion and recommendations}

Waste minimisation, community based waste management, environmental education, law enforcement and safe disposal were found to be the best practices in promoting a safe and healthy environment. Waste management is a global environmental issue which concerns about a very significant problem in today's world. This view is also shared by Lomborg [27] as he indicated in his book, "The Skeptical Environmentalist...", that "we will not be inundated with garbage. Garbage is something we can deal with, it is a management problem". There is a considerable amount of disposal of waste without proper segregation which has led to both economic, social and environment sufferings. 


\section{Acknowledgements}

We are grateful to the Department of Science and Technology (DST) and National Research Foundation (NRF) for funding this study. Walter Sisulu University is also thanked for logistic support.

\section{References}

[1] Xudong, C. Spatial Analysis and Evaluation System for the Planning of Regional Recycling Network: Empirical and Modeling Analyses in Japan. Nagoya University. Japan. 2012.

[2] Gondo, T. Spatial Planning and Open Space Integration in Urban Ethiopia: a Sustainable Accessibility Exegesis. REAL CORP 2012, Tagungsband Schwechat. http://www.corp.at. 2012.

[3] Ogunfowokan, A.O. Okoh, E.K. Adenuga, A.A. \& Asubiojo, O.I. An assessment of the impact of point source pollution from a university sewage treatment oxidation pond on a receiving stream - a preliminary study. Journal of Applied Sciences, Vol. 5, No 1. 2005.

[4] Taiwo, A.M. Adeogun, A.O. Olatunde, K.A. \& Adegbite, K.I. Analysis of groundwater quality of hand-dug wells in peri-urban areas of Obantoko, Nigeria. Pacific Journal of Science and Technology, Vol. 12, No. 1. 2011.

[5] Hayashi, Y. Can We Design the Future of Human Life and the Environment? Sustainability: Future Balance between Nature and Civilization. Tokyo, Japan: Akashi Shoten. 2010.

[6] Mahdavinejada, M. \& Abedia, M. Community-oriented landscape design for sustainability in architecture and planning. Procedia Engineering. 2011.

[7] Kalule, S.K. Integrated Waste Management Plan, O.R. Tambo District Municipality. Usk Consulting Environmental \& Waste. Eastern Cape South Africa. 2009.

[8] Williams, P.T. Waste Treatment and Disposal, second edition, the University of Leeds, UK. 2005.

[9] Taiwo, A.M. Olujimi2, O.O. Bamgbose O. \& Arowolo, T.A. Surface Water Quality Monitoring in Nigeria: Situational Analysis and Future Management Strategy. InTechOpen, Nigeria. 2012.

[10] Rahardyan. B. Matsuto. T. Kakuta. Y. \& Tanaka. N. Resident's concerns and attitudes towards Solid Waste Management Facilities. Hokkaido University. Japan. 2004.

[11] Izonfuo, L.W.A. \& Bariweni, A.P. The effect of urban runoff water and human activities on some physico- chemical parameters of the Epie Creek in the Niger Delta. Journal of Applied Science and Environmental Management, Vol. 5, No. 1. ISSN 1119-8362. 2001.

[12] Taiwo, A.M. Environmental impact of poultry farm operations on Alakata Stream at Isolu in Abeokuta, Nigeria. Unpublished Master's Thesis. University of Agriculture, Abeokuta. 2010.

[13] Pankaj Kumar, K.L. Jetani, S.I. Yusuzai, A.N. Sayani, Ahamd, S.D. \& Rather, M.A. Effect of sediment and water quality parameters on the 
productivity of coastal shrimp farm. College of Fisheries Junagadh Agricultural University, Veraval, Gujarat. Pelagia research library, USA. 2012.

[14] Nagendra, K.C. \& Tiwari, R.K. Effect of industrial effluents and wastes on physico-chemical parameters of river Rapti. Sant Ravi Das Nagar. Pelagia research library, USA. 2011.

[15] Ogunfowokan, A.O. Okoh, E.K. Adenuga, A.A \& Asubiojo, O.I. An assessment of the impact of point source pollution from a university sewage treatment oxidation pond on a receiving stream - a preliminary study. Journal of Applied Sciences, Vol. 5, No 1. Doi: 10.3923/jas. 2005.

[16] Hemant, P. Deepak, P. \& Limaye, S.N. Studies on the physico-chemical status of two water bodies at Sagar city under anthropogenic influences. Department of Chemistry, Engineering College, Sagar. Pelagia research library, USA. 2012.

[17] Ibiyemi, A.O. Evaluating validity of contingent valuation model for household Willingness-to-Accept near Olusosun Waste Disposal Site, Lagos. 2000.

[18] Kimani, N.G. Environmental Pollution and Impact to Public Health; Implication of the Dandora Municipal Dumping Site in Nairobi. UNEP, Kenya. 2007.

[19] World Health Organisation (WHO). Children's Health and the Environment, A global Perspective: a resource manual for the health sector. Pronczuk de Garbino. 2005.

[20] Owusu, G. Social effects of poor sanitation and waste management on poor urban communities. Journal of Urbanism: International Research on Placemaking and Urban Sustainability. Institute of Statistical, Social and Economic Research (ISSER), University of Ghana, Legon, Ghana. 2010.

[21] Bandara, N.J.G.J. \& Hettiarachchi, P.J. Environmental Impacts Associated with Current Waste Disposal Practices in a Municipality in Sri Lanka. Workshop on Sustainable Landfill Management. Chennai, India. 2003.

[22] Rathi, S. Alternative approaches for better municipal solid waste management in Mumbai, India. International Research Institute for Climate Prediction, The Earth Institute, Columbia University, USA. 2005.

[23] UNCHS (Habitat). The State of the Worlds Cities 2001, Nairobi, Kenya. 2001.

[24] Onibokun, A.G. Managing the monster: Urban waste and governance in Africa. Canada, International Development Research Centre (IDRC). 2004.

[25] Bai, R.B. \& Sutanto, M. The practice and challenges of solid waste management in Singapore. Waste Management, 2002.

[26] Hostovsky, C. The Paradox of the Rational Comprehensive Model of Planning: Tales from Waste Management Planning in Ontario, Canada. Journal Of Planning Education And Research, 25(4), 2006.

[27] Lomborg, B. The skeptical environmentalist: measuring the real state of the world. London, Cambridge University Press. 2001. 